\title{
How does malaria in pregnancy impact malaria risk in infants?
}

\author{
Prasanna Jagannathan
}

\begin{abstract}
Malaria in pregnancy not only exerts profound negative consequences on the health of the mother and developing fetus, but may also alter the risk of malaria during infancy. Although mechanisms driving this altered risk remain unclear, in utero exposure to malaria antigens may impact the development of fetal and infant innate immunity. In an article in BMC Medicine, Natama et al. describe an ambitious analysis of basal and TLR-stimulated cord blood responses among a birth cohort in Burkina Faso. Basal levels of several cytokines, chemokines, and growth factors were shown to be significantly lower in cord blood with histopathologic evidence of placental malaria. Additionally, following TLR7/8 stimulation, samples obtained from infants of mothers with placental malaria were hyper-responsive compared to those without evidence of prenatal malaria exposure. Furthermore, several responses impacted by placental malaria were associated with differential malaria risk in infancy. Understanding how malaria in pregnancy shapes immune responses in infants will provide critical insight into the rational design of malaria control strategies during pregnancy, including intermittent preventative treatment in pregnancy and vaccines.
\end{abstract}

Please see related article: https://bmcmedicine.biomedcentral.com/articles/10.1186/s12916-018-1187-3

Keywords: Malaria, innate immunity, malaria in pregnancy, cord blood, TLR stimulation

\section{Background}

Malaria in pregnancy remains a significant problem across sub-Saharan Africa, exerting profound negative consequences on the health of the mother and developing fetus [1]. Additionally, there is increasing evidence that malaria exposure in utero may alter the risk of malaria and non-malarial febrile infections in infancy, with studies showing that offspring of women who experience malaria in pregnancy are at increased risk of malaria themselves [2-5]. However, it remains unclear whether these associations are a direct result of malaria in pregnancy or rather reflect shared environmental exposures between maternal-infant pairs.

The use of multiple definitions of malaria exposure during pregnancy complicates the evaluation of the impact of such exposure on infancy. Although Plasmodium falciparum infection in pregnancy can be detected in maternal peripheral blood, it is also sequestered in the placenta through binding to chondroitin sulfate A expressed on the placental syncytiotrophoblast via the

Correspondence: prasj@stanford.edu

Department of Medicine, Stanford University, Stanford, USA parasite molecule VAR2CSA [6, 7]. Importantly, not all women with $P$. falciparum infection detected in peripheral blood have evidence of placental malaria [8], and these overlapping definitions of malaria exposure in pregnancy may exert differential impacts on the developing fetus.. Further, several strategies for diagnosing placental malaria can be utilized, including assessment of placental blood to detect parasites and histopathologic evaluation to detect parasites, hemozoin pigment, or both. Identification and classification of these pathologic findings as either active infection (detection of parasites with (acute) or without (chronic) hemozoin) versus past infection (detection of hemozoin pigment alone) has been associated with differential impacts on infant outcomes, including adverse birth outcomes such as preterm birth [6, 9-11].

Although there are several potential mechanisms by which maternal malaria may impact the risk of malaria in infancy, it is increasingly appreciated that malaria in pregnancy may directly impact the development of the fetal and infant immune system $[12,13]$. However, the precise mechanisms by which malaria in pregnancy may impact

(c) The Author(s). 2018 Open Access This article is distributed under the terms of the Creative Commons Attribution 4.0 International License (http://creativecommons.org/licenses/by/4.0/), which permits unrestricted use, distribution, and reproduction in any medium, provided you give appropriate credit to the original author(s) and the source, provide a link to the Creative Commons license, and indicate if changes were made. The Creative Commons Public Domain Dedication waiver (http://creativecommons.org/publicdomain/zero/1.0/) applies to the data made available in this article, unless otherwise stated. 
the risk of malaria in infancy remain elusive. Furthermore, it remains unclear whether alterations in fetal and infant immunity induced by malaria in pregnancy are then causally responsible for alterations in malaria risk in infants.

\section{Impact of malaria in pregnancy on innate immune responsivity in infants}

Several studies have investigated the effect of malaria in pregnancy on innate immune responses in the neonate, particularly focusing on the activation of antigen presenting cells following stimulation with toll like receptor (TLR) ligands [14-16]. These studies have tested the hypothesis that in utero malaria antigen exposure may drive abnormal antigen presenting cell activation, leading to parasite-specific tolerance and an increased risk of infection in infants. Stimulation with polyinosinic-polycytidylic acid (TLR3), LPS (TLR4), and/or CpG oligonucleotide type A (TLR9) has been associated with altered cytokine production in whole cord blood [16] or cord blood mononuclear cells [14, 15 ] isolated from infants born to mothers exposed to malaria in pregnancy. Furthermore, increased cord blood production of IL-10 after TLR3 or TLR7/8 (resiquimod) stimulation was associated with an increased risk of $P$. falciparum infection during infancy [16], suggesting clinical consequences of differential TLR signaling at birth. However, these studies were limited by the panel of cytokines tested, as well as by the varying (and non-specific) definitions of malaria exposure in pregnancy.

Natama et al. [17] undertook an ambitious analysis of cord blood innate cell responsivity to TLR stimulation among a well-characterized birth cohort in a highly malaria endemic setting in Burkina Faso, posing two overarching questions. Firstly, what impact do different manifestations of malaria in pregnancy have on a broad panel of cytokines, chemokines, and growth factors measured at birth, both at baseline and following TLR-stimulation? Secondly, is basal or TLR-stimulated cytokine production at birth associated with protection from malaria in infancy? The study involved cord blood obtained from 313 maternal-infant pairs enrolled in a clinical trial in Burkina Faso assessing novel interventions to prevent malaria in pregnancy [18]. In this trial, pregnant women were enrolled and followed by both active and passive surveillance for malaria infection during pregnancy; at delivery, placental tissue was examined for histopathologic evidence of placental malaria as defined above. Infants born to these mothers were followed through 1 year of age. Natama et al. [17] assayed a panel of 30 cytokines, chemokines, and growth factors in whole cord blood supernatants by Luminex following stimulation with TLR3, 7/8, and 9 agonists, or unstimulated controls. The authors first looked for associations between malaria exposure in pregnancy and these immune features, and then evaluated whether basal or TLR-stimulated immune profiles at birth were associated with differential malaria risk in the first year of life. Basal levels of several immune features, including cytokines (e.g., IFN- $\alpha$, IL-1 $\beta$, IL-1RA, TNF, IFN- $\gamma$, IL-10), chemokines (e.g., MIP-1 $\alpha$, Rantes), and growth factors (e.g., G-CSF, GM-CSF, FGF), were found to be significantly lower in samples with evidence of malaria in pregnancy than in those that were unexposed. However, cord blood samples obtained from infants with evidence of 'past' placental malaria showed increased responsivity to TLR7/8 stimulation.

One potential explanation for these results is the possibility of differential admixture of cells in cord blood from infants exposed to malaria in utero, though cord blood cellular populations were not measured in this study. Indeed, malaria in pregnancy has been associated with increased myeloid dendritic cells in cord blood $[19,20]$ and malaria pigment in the placenta has also been associated with 'partial maturation' of cord blood myeloid and plasmacytoid dendritic cells [15]. However, an alternative explanation is that malaria exposure in pregnancy may alter innate cell responsivity, including the possibility that malaria exposure may induce 'trained' innate immunity, as has recently been suggested [21], though this remains to be determined.

Importantly, the authors found that several immunologic features impacted by placental malaria exposure were also associated with differential malaria risk in infancy. For example, higher concentrations of GM-CSF and eotaxin following TLR7/8 stimulation, of IL-1 $\beta$ following TLR9 stimulation, and of IL-7 following IL-3 stimulation, were associated with an increased hazard of malaria in the first year of life. In contrast, a higher concentration of IP-10 following TLR3 or TLR9 stimulation was associated with a lower hazard of malaria. Taken together, these data suggest that placental malaria may influence cord blood responsivity, and that these alterations may impact the subsequent risk of malaria early in life.

\section{Conclusion}

Malaria during pregnancy may lead to significant and long-lasting effects on the infant, including a predisposition to a greater risk of malaria in early life. By finding that placental malaria may impact innate immune responsivity in infants, and that these alterations may be associated with differential malaria risk in infants, Natama et al. [17] suggest a potential mechanism for this epidemiologic association. Future studies will need to evaluate whether (and how) malaria in pregnancy may perturb innate cellular populations, including whether placental malaria may drive intrinsic changes within these cells. Furthermore, mechanistic studies should attempt to determine whether these immunologic correlates are causally responsible for the associations observed. An improved understanding of how malaria in pregnancy shapes immune responses in infants may provide important insights into the rational design and development of malaria control strategies in pregnancy. 
Funding

No dedicated funding was required for preparation of the Commentary.

\section{Author's contributions}

Dr. Jagannathan wrote and approved the final manuscript.

\section{Ethics approval}

Not applicable.

\section{Competing interests}

The author declares that he has no competing interests.

\section{Publisher's Note}

Springer Nature remains neutral with regard to jurisdictional claims in published maps and institutional affiliations.

\section{Received: 10 October 2018 Accepted: 6 November 2018}

\section{Published online: 20 November 2018}

\section{References}

1. Walker PG, ter Kuile FO, Garske T, Menendez C, Ghani AC. Estimated risk of placental infection and low birthweight attributable to Plasmodium falciparum malaria in Africa in 2010: a modelling study. Lancet Glob Health. 2014;2(8):e460-7.

2. Le Hesran JY, Cot M, Personne P, Fievet N, Dubois B, Beyeme M, Boudin C, Deloron P. Maternal placental infection with Plasmodium falciparum and malaria morbidity during the first 2 years of life. Am J Epidemiol. 1997; 146(10):826-31.

3. Mutabingwa TK, Bolla MC, Li JL, Domingo GJ, Li X, Fried M, Duffy PE. Maternal malaria and gravidity interact to modify infant susceptibility to malaria. PLoS Med. 2005;2(12):e407.

4. Schwarz NG, Adegnika AA, Breitling LP, Gabor J, Agnandji ST, Newman RD, Lell B, Issifou S, Yazdanbakhsh M, Luty AJ, et al. Placental malaria increases malaria risk in the first 30 months of life. Clin Infect Dis. 2008;47(8):1017-25.

5. Bardaji A, Sigauque B, Sanz S, Maixenchs M, Ordi J, Aponte JJ, Mabunda S, Alonso PL, Menendez C. Impact of malaria at the end of pregnancy on infant mortality and morbidity. J Infect Dis. 2011;203(5):691-9.

6. Brabin BJ, Romagosa C, Abdelgalil S, Menendez C, Verhoeff FH, McGready R, Fletcher KA, Owens S, D'Alessandro U, Nosten F, et al. The sick placenta-the role of malaria. Placenta. 2004;25(5):359-78.

7. Fried M, Duffy PE. Adherence of Plasmodium falciparum to chondroitin sulfate A in the human placenta. Science. 1996;272(5267):1502-4.

8. Boudova S, Divala T, Mungwira R, Mawindo P, Tomoka T, Laufer MK. Placental but Not Peripheral Plasmodium falciparum Infection During Pregnancy Is Associated With Increased Risk of Malaria in Infancy. J Infect Dis. 2017:216(6):732-5.

9. Rogerson SJ, Hviid L, Duffy PE, Leke RF, Taylor DW. Malaria in pregnancy: pathogenesis and immunity. Lancet Infect Dis. 2007:7(2):105-17.

10. Kapisi J, Kakuru A, Jagannathan $P$, Muhindo MK, Natureeba P, Awori P, Nakalembe M, Ssekitoleko R, Olwoch P, Ategeka J, et al. Relationships between infection with Plasmodium falciparum during pregnancy, measures of placental malaria, and adverse birth outcomes. Malar J. 2017;16(1):400

11. Muehlenbachs A, Fried M, McGready R, Harrington WE, Mutabingwa TK, Nosten F, Duffy PE. A novel histological grading scheme for placental malaria applied in areas of high and low malaria transmission. J Infect Dis. 2010;202(10):1608-16.

12. Harrington WE, Kakuru A, Jagannathan P. Malaria in pregnancy shapes the development of foetal and infant immunity. Parasite Immunol. 2018:e12573. https://doi.org/10.1111/pim.12573. Epub ahead of print.

13. Odorizzi PM, Feeney ME. Impact of In Utero Exposure to Malaria on Fetal T Cell Immunity. Trends Mol Med. 2016;22(10):877-88.

14. Adegnika AA, Kohler C, Agnandji ST, Chai SK, Labuda L, Breitling LP, Schonkeren D, Weerdenburg E, Issifou S, Luty AJ, et al. Pregnancyassociated malaria affects toll-like receptor ligand-induced cytokine responses in cord blood. J Infect Dis. 2008;198(6):928-36.

15. Fievet N, Varani S, Ibitokou S, Briand V, Louis S, Perrin RX, Massougbogji A, Hosmalin A, Troye-Blomberg M, Deloron P. Plasmodium falciparum exposure in utero, maternal age and parity influence the innate activation of foetal antigen presenting cells. Malar J. 2009;8:251.

16. Gbedande K, Varani S, Ibitokou S, Houngbegnon P, Borgella S, Nouatin O, Ezinmegnon S, Adeothy AL, Cottrell G, Massougbodji A, et al. Malaria modifies neonatal and early-life toll-like receptor cytokine responses. Infect Immun. 2013:81(8):2686-96.

17. Natama H, Moncunill G, Rovira-Vallbona E, Sanz H, Sorgho H, Aguilar R, Coulibaly-Traore M, Some MA, Scott S, Valea I, et al. Modulation of innate immune responses at birth by prenatal malaria exposure and association with malaria risk during the first year of life. BMC Med. 2018;16(1):198.

18. COSMIC Consortium. Community-based Malaria Screening and Treatment for Pregnant Women Receiving Standard Intermittent Preventive Treatment With Sulfadoxine-Pyrimethamine: A Multicenter (The Gambia, Burkina Faso, and Benin) Cluster-randomized Controlled Trial. Clin Infect Dis. 2018. 10. 1093/cid/ciy522. Epub ahead of print.

19. Breitling LP, Fendel R, Mordmueller B, Adegnika AA, Kremsner PG, Luty AJ. Cord blood dendritic cell subsets in African newborns exposed to Plasmodium falciparum in utero. Infect Immun. 2006;74(10):5725-9.

20. Prahl M, Jagannathan $P$, Mclntyre TI, Auma A, Farrington L, Wamala S, Nalubega M, Musinguzi K, Naluwu K, Sikyoma E, et al. Timing of in utero malaria exposure influences fetal CD4 T cell regulatory versus effector differentiation. Malar J. 2016;15(1):497.

21. Schrum JE, Crabtree JN, Dobbs KR, Kiritsy MC, Reed GW, Gazzinelli RT, Netea MG, Kazura JW, Dent AE, Fitzgerald KA, et al. Cutting Edge: Plasmodium falciparum Induces Trained Innate Immunity. J Immunol. 2018;200(4):1243-8.
Ready to submit your research? Choose BMC and benefit from:

- fast, convenient online submission

- thorough peer review by experienced researchers in your field

- rapid publication on acceptance

- support for research data, including large and complex data types

- gold Open Access which fosters wider collaboration and increased citations

- maximum visibility for your research: over $100 \mathrm{M}$ website views per year

At $\mathrm{BMC}$, research is always in progress.

Learn more biomedcentral.com/submissions 